Pesq. Vet. Bras. 35(1):39-43, janeiro 2015

DOI: 10.1590/S0100-736X2015000100009

\title{
Development of a Real-time PCR test for porcine group A rotavirus diagnosis ${ }^{1}$
}

\author{
Elizabeth C.M. Marconi², Nara T.C.G. Bernardes², Laila A.R. Beserra², \\ Fernanda D.F. Silva ${ }^{2}$ and Fabio Gregori ${ }^{2 *}$
}

\begin{abstract}
Marconi E.C.M., Bernardes N.T.C.G., Beserra L.A.R., Silva F.D.F. \& Gregori F. 2015. Development of a Real-time PCR test for porcine group A rotavirus diagnosis. Pesquisa Veterinária Brasileira 35(1):39-43. Departamento de Medicina Veterinária Preventiva e Saúde Animal, Universidade de São Paulo, Av. Professor Dr. Orlando Marques de Paiva 87, São Paulo, SP 05508-270, Brazil. E-mail: fabiogregori@gmail.com

Group A Rotavirus (RVA) is one of the most common causes of diarrhea in humans and several animal species. A SYBR-Green Real-Time polymerase chain reaction (PCR) was developed to diagnose RVA from porcine fecal samples, targeting amplification of a 137-bp fragment of nonstructural protein 5 (NSP5) gene using mRNA of bovine NADH-desidrogenase-5 as exogenous internal control. Sixty-five samples were tested (25 tested positive for conventional PCR and genetic sequencing). The overall agreement (kappa) was 0.843 , indicating 'very good' concordance between tests, presenting $100 \%$ of relative sensitivity (25+ Real Time PCR/25+ Conventional PCR) and $87.5 \%$ of relative sensitivity (35- Real Time PCR/40- Conventional PCR). The results also demonstrated high intra- and inter-assay reproducibility (coefficient of variation $\leq 1.42 \%$ ); thus, this method proved to be a fast and sensitive approach for the diagnosis of RVA in pigs.
\end{abstract}

INDEX TERMS: Rotavirus, diagnosis, PCR, Real-Time PCR, NSP5, swine.

RESUMO.- [Desenvolvimento de um teste de PCR em Tempo Real para o diagnóstico de rotavírus suínos do Grupo A.] Rotavírus do grupo A (RVA) é uma das causas mais frequentes de diarreias em humanos e várias espécies animais. Um teste de PCR em Tempo Real com SYBR-Green foi desenvolvido visando o diagnóstico de RVA a partir de fezes suínas, através da amplificação de um fragmento de 137 pares de bases do gene da proteína não estrutural 5 (NSP5) viral e de mRNA de NADH-desidrogenase-5 bovina como controle interno exógeno. Foram testadas 65 amostras (25 delas positivas por PCR convencional e sequenciamento nucleotídico). A concordância entre os testes foi de 0,843 , considerada "muito boa", apresentando $100 \%$ de sensibilidade relativa (25+ PCR Tempo Real/25+ PCR convencional) e $87,5 \%$ de sensibilidade relativa (35- PCR Tempo Real/40- PCR convencional). Os resultados também demonstraram elevada reprodutibilidade inter e intra-ensaio

\footnotetext{
${ }^{1}$ Received on September 26, 2014.

Accepted for publication on January 19, 2015.

2 Departamento de Medicina Veterinária Preventiva e Saúde Animal, Universidade de São Paulo, Av. Professor Dr. Orlando Marques de Paiva 87, São Paulo, SP 05508-270, Brazil. *Corresponding auhor: fabiogregori@ gmail.com
}

(coeficiente de variação $\leq 1,42 \%$ ); portanto, este método demonstrou ser uma rápida e sensível alternativa para o diagnóstico de RVA em suínos.

TERMOS DE INDEXAÇÃO: Rotavírus, diagnóstico, PCR, PCR em Tempo Real, NSP5, suínos.

\section{INTRODUCTION}

Group A rotavirus (RVA) is one of the main causative agents of diarrhea in a variety of animal species, as reported in several countries (Estes \& Kapikian 2007). RVA infection is common in swine farms, and it results in decreased growth performance, increased mortality and economic loss (Papp et al. 2013).

RVA belongs to Family Reoviridae, Subfamily Sedoreovirinae, Genus Rotavirus, and its genome consists of 11 double-stranded RNA (dsRNA) segments, coding for 6 structural (VP1, VP2, VP3, VP4, VP6, VP7) and 6 non-structural proteins (NSP1 through 6) (King et al. 2012).

Diagnosis of RVA infection plays a central role in establishing measures for control and prevention. The methods currently available, the polyacrylamide gel electrophoresis (PAGE) technique (Herring et al. 1982) allows the detection of all rotavirus strains regardless of the group to which 
they belong; however, it is time consuming and inefficient to process a large number of clinical samples. The enzyme-linked immunosorbent assay (ELISA) overcomes these difficulties; however, it is capable of detecting only a restricted number of viral groups and presents limitations of availability and quality of antibodies required (Jerez 1997, $\mathrm{Zhu}$ et al. 2013). Conventional polymerase chain reaction (PCR) is advantageous as a rapid procedure, described in routine practice by several authors (Dhama et al. 2009), while Real-time PCR provides higher sensitivity, throughput, and may reduce cross-contamination, since there is no need of post-PCR manipulations (Pestana et al. 2010, Mijatovic-Rustempasic et al. 2013).

RVA have undergone various changes during evolution, including point mutations, reassortment, rearrangement, and intragenic recombination (Ghosh \& Kobayashi 2011), which has resulted in a large variability in genotypes (Matthijnssens et al. 2011) as well as intra-genotypic variations (Gregori et al. 2012, Amimo et al. 2013). Therefore, molecular diagnosis should take into consideration the fact that the primer hybridization sites are not always conserved, especially among viral strains that infect different host species, resulting in a greater likelihood of false-negative results, and requiring periodic review of these primers.

Despite their importance, diagnostic methods, such as PCR, which take genetic diversity into consideration, in particular, the diversity presented by porcine RVA, are scarce. This study describes the development of a SYBR-Green Real-time PCR assay for rapid and sensitive detection of porcine RVA in fecal material.

\section{MATERIALS AND METHODS}

RNA extraction and reverse transcription. Fecal suspensions $(50 \% \mathrm{w} / \mathrm{v})$ were prepared in ultrapure water previously treated with $0.1 \%$ diethyl pyrocarbonate (DEPC) and clarified by centrifugation at $12,000 \mathrm{~g}$ for $15 \mathrm{~min}$ at $4^{\circ} \mathrm{C}$. The supernatant from fecal suspensions and controls were subjected to RNA extraction with TRIzol reagent (Invitrogen Carlsbad, CA, USA) according to the manufacturer's instructions. At the end of procedure, RNA was solubilized in $15 \mu \mathrm{L}$ of ultrapure water pre-treated with $0.1 \%$ DEPC.

The reverse transcription (RT) reaction was performed according to the following protocol: The RNA sample $(7 \mu \mathrm{L})$ was denatured at $95^{\circ} \mathrm{C}$ for 5 min and immediately transferred into an ice bath for $10 \mathrm{~min}$. Then, denatured RNA was added to a RT-mix solution containing $1 \times$ First Strand Buffer, $1 \mathrm{mM}$ of each dNTP, $10 \mathrm{mM}$ of DTT, 50ng of random primers (Invitrogen, Carlsbad, CA, USA), $1 \mu \mathrm{L}$ of ultrapure water, and $200 \mathrm{U}$ of Superscript Reverse Transcriptase III (Invitrogen Carlsbad, CA, USA) in a final reaction volume of $20 \mu \mathrm{L}$. This was incubated at $37^{\circ} \mathrm{C}$ for $60 \mathrm{~min}$ and then at $70^{\circ} \mathrm{C}$ for $15 \mathrm{~min}$.

Primer design. A total of 34 RVA sequences encoding the non-structural protein NSP5, available in the GenBank database, were aligned using the ClustalW 2.1 software (Larkin et al. 2007). Primers were selected visually from conserved regions of the alignment, being designated NSP5FW1 (5' GGCTTTTAAAGCGCTACAG 3') and NSP5RV137 (5' TGTTCACTCCTACCAATAGATTT 3'), generating a fragment of 137 -bp (base pairs). These sequences were submitted to BLAST/ $\mathrm{n}$ to verify its analytical specificity, whereas the formation of dimers, hairpins, and melting temperature $\left(\mathrm{T}_{\mathrm{m}}\right)$ were assessed with the OligoAnalyzer 3.1 software (www.idtdna. com).
Production of plasmids. To establish the Real-time PCR standard curve, a 137-bp PCR product of the gene encoding NSP5 of porcine RVA was used, with a previously known nucleotide sequence, cloned into pTZ57R/T vector (Fermentas, Waltham, MA, USA), according to the manufacturer's protocol. The resulting plasmid was transformed into Escherichia coli DH5 $\alpha$ cells and then purified using the NucleoSpin Plasmid Prep kit (Macherey-Nagel, Düren, Germany). The cloned DNA fragments were linearized by digestion with the enzyme EcoRI (BioLabs Ipswich, MA, USA) following manufacturer's instructions, quantified by NanoDrop 2000 (Thermo Scientific, Waltham, MA, USA) spectrophotometer, and stored at $-80^{\circ} \mathrm{C}$ until use.

Real-Time PCR. Assays were performed using Maxima SYBR Green qPCR/ROX Master Mix (Fermentas, Waltham, MA, USA) in a StepOne Real-time PCR System (Applied Biosystems, Waltham, MA, USA). The procedures were optimized for primer concentration and annealing temperature, using RVA 32/00 as reference strain (Rodriguez et al. 2004) and seven swine feces samples serially screened as positive by PAGE (Herring et al. 1982) and ELISA (Gregori et al. 2000).

SYBR Green Real-Time PCR reaction consisted of $12.5 \mu \mathrm{L}$ of Maxima SYBR Green/ROX qPCR Master Mix $(2 \times), 0.3 \mu \mathrm{M}$ of each primer (NSP5FW1/NSP5RV137), $2 \mu \mathrm{L}$ of cDNA, and up to $25 \mu \mathrm{L}$ of ultrapure water. The conditions were as follows: $95^{\circ} \mathrm{C}$ for 10 min; 40 cycles at $95^{\circ} \mathrm{C}$ for $1 \mathrm{~min}, 54^{\circ} \mathrm{C}$ for $1 \mathrm{~min}$, and $72^{\circ} \mathrm{C}$ for $1 \mathrm{~min}$, followed by a standard melting curve $\left(95^{\circ} \mathrm{C}\right.$ for $15 \mathrm{~s}, 60^{\circ} \mathrm{C}$ for 1 min, and $95^{\circ} \mathrm{C}$ for $15 \mathrm{~s}$ with a reading at every $0.3^{\circ} \mathrm{C}$ ) to assess the specificity of PCR according to the $\mathrm{T}_{\mathrm{m}}$ profile of the reference strain.

A total of 65 porcine fecal samples from piglets aged less than 40 days old were tested using the Real-time PCR assay, 25 of which were previously positive by conventional PCR using primers described by Salem et al. (2010) and confirmed by the respective genetic sequencing of the NSP5 gene. Ultrapure water without template strand was used as negative control (NTC).

The exogenous internal control consisted of MDBK cells maintained in $25-\mathrm{cm}^{2}$ flasks with MEM medium supplemented by $5 \%$ fetal bovine serum. Cells were removed by scraping the monolayer, centrifuged at 5,000 $\mathrm{g}$ for $10 \mathrm{~min}$, reducing their volume to $500 \mu \mathrm{L}$.

Ten- $\mu \mathrm{L}$ MDBK cell precipitate were added to fecal suspension in the samples that were negative for rotavirus by Real-time PCR, and RNA extraction was performed as described previously. The samples were then tested by amplification of the messenger RNA (mRNA) of the gene encoding the mitochondrial bovine NADHdehydrogenase- 5 protein using a pair of primers (BOV-F and BOV-R), described by Caldwell, Raley \& Levine (2007), which generates a product of 191-bp. The following amplification conditions were used: $95^{\circ} \mathrm{C}$ for $10 \mathrm{~min}$; 40 cycles of $94^{\circ} \mathrm{C}$ for $1 \mathrm{~min}, 55^{\circ} \mathrm{C}$ for $2 \mathrm{~min}$, and $72^{\circ} \mathrm{C}$ for $1 \mathrm{~min}$, followed by a standard melting curve of the product $\left(95^{\circ} \mathrm{C}\right.$ for $15 \mathrm{~s}, 60^{\circ} \mathrm{C}$ for $1 \mathrm{~min}$, and $95^{\circ} \mathrm{C}$ for $15 \mathrm{~s}$ with a reading at every $0.3^{\circ} \mathrm{C}$ ). Negative results from this test were interpreted as inconclusive detection of RVA, presumably due to presence of PCR inhibitors.

Agreement was assessed using the Kappa test adopting a confidence interval of $95 \%$ along with the calculation of relative diagnostic sensitivity and specificity, by comparing the results of conventional PCR and Real-Time PCR for RVA (Thrusfield 2007).

Definition of analytical sensitivity and specificity. In order to determine the analytical sensitivity of the Real-time PCR method, a standard linearized plasmid was used as a template and serially diluted 10 -fold using ultrapure water previously treated with $0.1 \%$ DEPC, resulting in concentrations ranging from $1.04 \times$ $10^{1}$ to $1.04 \times 10^{5} \mathrm{DNA}$ copies $/ \mu \mathrm{L}$ in triplicate. The correlation coe- 
fficient $\left(\mathrm{r}^{2}\right)$ and the reaction efficiency (E) were calculated using the formula $\mathrm{E}=10^{(-1 / \text { slope) }}-1$ (Dorak 2006).

Six fecal samples classified as positive for rotavirus by Real-time PCR were selected along with the reference strain RVA $32 / 00$ to check the analytical specificity for rotavirus group A. For this purpose, the products of reverse transcription of these samples were subjected to a standard PCR reaction, using the same primers used in Real-time PCR, which in brief included $2.5 \mu \mathrm{L}$ of cDNA added to the PCR-mix, consisting of $1 \times$ PCR Buffer (Invitrogen Carlsbad, CA, USA), $0.2 \mathrm{mM}$ of each $\mathrm{dNTP}, 0.5 \mu \mathrm{M}$ of each primer (NSP5FW1 and NSP5RV137), 2mM of $\mathrm{MgCl}_{2}, 1.25 \mathrm{U}$ of Taq DNA Polymerase (Invitrogen Carlsbad, CA, USA), and water in a total of $25 \mu \mathrm{L}$. The products were then amplified using the following conditions: $95^{\circ} \mathrm{C}$ for $2 \mathrm{~min} ; 35$ cycles of $95^{\circ} \mathrm{C}$ for $1 \mathrm{~min}, 54^{\circ} \mathrm{C}$ for $1 \mathrm{~min}, 72^{\circ} \mathrm{C}$ for $1 \mathrm{~min} ; 72^{\circ} \mathrm{C}$ for $10 \mathrm{~min}$, and storage at $10^{\circ} \mathrm{C}$.

The 137-bp bands were purified directly from agarose gels using the Illustra GFX PCR DNA and Gel Band Purification Kit (GE Healthcare, Little Chalfont, Buckinghamshire, UK), added to bidirectional sequencing reactions using BigDye Reagent 3.1 (Applied Biosystems, Waltham, MA, USA), and analyzed in an ABI-3500 (Applied Biosystems, Waltham, MA, USA) genetic analyzer, in accordance with the manufacturer's protocol. The nucleotide sequences were submitted to BLAST/n to compare its identity with sequences from rotavirus group $A$.

Finally, the bovine coronavirus BCoV Kakegawa reference strain (Akashi et al. 1980) was subjected to Real-time PCR to identify possible cross amplification.

Assessment of reproducibility. The linearized standard plasmid was diluted in concentrations ranging from $1.04 \times 10^{1}$ to $1.04 \times 10^{5}$ DNA copies/ $\mu \mathrm{L}$ and subjected to Real-Time PCR. Each dilution was repeated 3 times (intra-assay variation) and processed on 3 different days (inter-assay variation) to define the coefficients of variation (CV) and average values of $\mathrm{C}_{\mathrm{t}}$ (cycle threshold).

\section{RESULTS}

\section{Primer design}

The $\mathrm{T}_{\mathrm{m}}$ values of the designed primers were similar $\left(51.8^{\circ} \mathrm{C}\right.$ for NSP5FW1 and $51.4^{\circ} \mathrm{C}$ for NSP5RV137), presenting the most stable heterodimer with a $\Delta \mathrm{G}$ value of -3.89 $\mathrm{kcal} \times$ mole $^{-1}$. In silico primer analysis demonstrated that NSP5FW1 and NSP5RV137 had E values of 0.41 and 0.003 on BLAST/n, respectively, as well as, each one had $100 \%$ identity to at least 250 target sequences of rotavirus. The most stable homodimer had $\Delta \mathrm{G}$ values of $-13.09 \mathrm{kcal} \times$ mole $^{-1}$ and $-3.42 \mathrm{kcal}^{\circ} \times$ mole $^{-1}$; and the hairpin had values of $-1.72 \mathrm{kcal} \times \mathrm{mole}^{-1}$ and $-3.42 \mathrm{kcal} \times \mathrm{mole}^{-1}$ for the primers NSP5FW1 and NSP5RV, respectively.

\section{Detection in clinical samples and correlation with con- ventional PCR}

Swine fecal samples were tested using Real-Time and conventional PCR tests, results of which are shown in Table 1 . The positive samples showed a $C_{t}$ between 19.53 and 39.43 , with greater frequency $(81.25 \%)$ between the range of 25.59 and 36.58 .

The melting curve profile was similar in the positive and standard samples (average $\mathrm{T}_{\mathrm{m}}=75.12 \pm 0.16^{\circ} \mathrm{C}$ ). In the negative samples, fragments the coding gene of the mitochondrial bovine NADH-dehydrogenase-5 protein were subsequently detected, validating the extraction and amplification procedures, and their $C_{t}$ values ranged from 22.07 and 27.11 , with an average $\mathrm{T}_{\mathrm{m}}$ of $78.76 \pm 0.28^{\circ} \mathrm{C}$. With respect to the no template control (NTC), all replicates were negative as expected.

The relative diagnostic sensitivity between the tests was $100 \%$ (CI95\% 0.863-1), and the relative diagnostic specificity was $87.5 \%$ (CI95\% 0,732-0,958). The agreement can be considered 'very good', with a Kappa value of 0.843 (CI95\% 0.713 - 0.974).

\section{Analytical sensitivity and specificity}

Adequate linear relationship was observed between concentrations ranging from $1.04 \times 10^{1}$ to $1.04 \times 10^{5}$ DNA copies $/ \mu \mathrm{L}$ of the linearized plasmid with a correlation coefficient $\left(\mathrm{r}^{2}\right)$ of 0.998 and efficiency of $102.21 \%$. Quantitative data showed that the detection limit of Real-Time PCR was $1.04 \times 10^{1}$ copies $/ \mu \mathrm{L}$.

The sequencing of seven PCR products, generated using primers NSP5FW1 and NSP5RV137 (six fecal samples and standard sample 32/00), showed high identity (98\%$100 \%$ ) with different strains of RVA, including KC117151 of porcine origin. This confirmed the analytical specificity of the fragment generated.

The bovine BCoV Kakegawa coronaviruse showed no sign of cross-amplification using Real-Time PCR.

\section{Reproducibility}

The reproducibility of the assay, using triplicates of each dilution of linearized standard plasmid for reactions of Real-Time PCR, are presented in Table 2. The coefficients of intra- and inter-assay variations were relatively small $(<1.42 \%)$, ranging between $0.27 \%$ to $0.87 \%$ and $0.53 \%$ to $1.42 \%$, respectively.

\section{DISCUSSION}

The gene encoding NSP5, located in segment 11, is $667 \mathrm{bp}$ in length (referring to the RV SA11 sample) and this protein interacts with other proteins and viral RNA (Contin et al.

Table 1. Results of Real-time (qPCR) and conventional PCR used for diagnosis of porcine RVA detection

\begin{tabular}{lcccc}
\hline & & \multicolumn{2}{c}{ Conventional PCR } & \\
\cline { 3 - 4 } & & Positive & Negative & Total \\
\hline qPCR & Positive & 25 & 5 & 30 \\
& Negative & 0 & 35 & 35 \\
Sensitivity & Total & 25 & 40 & 65 \\
Specificity & & $100 \%($ CI95\% $0.863-1)$ & \\
Kappa value & & $87.5 \%($ CI95\% $0,732-0,958)$ & \\
& & $0.843($ CI95\% $0.713-0.974)$ &
\end{tabular}

Table 2. Reproducibility of Real-time PCR assay used for detection of a fragment of the NSP5 gene of porcine RVA

\begin{tabular}{|c|c|c|c|c|c|c|c|}
\hline \multirow{2}{*}{$\begin{array}{l}\text { Concentration of the } \\
\text { standard plasmid } \\
\text { (DNA copies } / \mu \mathrm{L} \text { ) }\end{array}$} & \multirow[b]{2}{*}{$\mathrm{n}$} & \multicolumn{3}{|c|}{ Intra-assay } & \multicolumn{3}{|c|}{ Inter-assay } \\
\hline & & Average $\mathrm{C}$ & SD & $\% \mathrm{CV}$ & Average Ct & SD & $\% \mathrm{CV}$ \\
\hline & 3 & 18.28 & 0.16 & 0.87 & 18.39 & 0.09 & 0.53 \\
\hline & 3 & 21.83 & 0.06 & 0.27 & 21.42 & 0.30 & 1.42 \\
\hline $1.04 \times 103$ & 3 & 25.25 & 0.18 & 0.71 & 25.52 & 0.19 & 0.76 \\
\hline $1.04 \times 102$ & 3 & 28.35 & 0.14 & 0.49 & 28.40 & 0.24 & 0.85 \\
\hline $1.04 \times 101$ & 3 & 31.37 & 0.19 & 0.60 & 31.49 & 0.14 & 0.46 \\
\hline
\end{tabular}


2010, King et al. 2012). Its main function is to participate in the formation of viroplasms, which are cytoplasmic structures where genome replication and morphogenesis of new particles occurs (Criglar et al. 2014). Among porcine strains, previous data showed low rates of genetic variability NSP5/6, because their structural and functional constraints and lower exposure to immune selection (Barbosa et al. 2013), which is a desirable property when selecting targets for nucleic acid detection methods.

The primers designed for the coding segment of porcine group A rotavirus NSP5 protein showed consensus areas with the 34 porcine sequences retrieved from GenBank, while the BLAST/n query resulted in high nucleotide identity of the rotavirus strains. There was an effective amplification of target product during the assay, and despite the presence of homo-dimers and hairpins, these presented high $\Delta \mathrm{G}$ values (Santalucia 2007), demonstrating the overall suitability of the primer design.

We opted for the reverse transcription step with random primers to allow for screening of other potential viral agents from cDNA, including coronaviruses and even of other rotavirus genes, giving greater versatility to the test. However, differences between the annealing temperatures of the primers prevented the detection of the target gene and the exogenous internal control in a single temperature cycle. Nevertheless, we included the mitochondrial mRNA encoding bovine NADH-dehydrogenase- 5 (Caldwell et al. 2007) based on a favorable report by Asano et al. (2010), who used this control to validate a PCR assay for the VP1 gene of RV, in agreement with our finding of accurate detection in Real-Time PCR, where $C_{t}$ values between 22.07 and 27.11 and low variability in $\mathrm{T}_{\mathrm{m}}\left(78.76 \pm 0.28^{\circ} \mathrm{C}\right)$ was obtained.

Comparing results from conventional PCR with Real-Time PCR, 100\% relative diagnostic sensitivity between tests and relative diagnostic specificity of $87.5 \%$ was obtained, as presented in Table 1 . The agreement value (84.3\%) showed a disparity in 5 samples between the results from conventional and Real-Time PCR techniques.

A possible explanation is an eventual 'false-positive' result generated by Real-time PCR. Meanwhile, these 5 samples presented a melting curve with the same profile shown by other samples and standard RVA (average $\mathrm{T}_{\mathrm{m}}=$ $75.12 \pm 0.16^{\circ} \mathrm{C}$ ), with $C_{t}$ between 31.62 and 39.43 . Additionally, genetic sequencing of the generated fragments confirmed that all had identity with rotavirus, implying that differences in detection thresholds of the tests were observed, thus increasing the diagnostic sensitivity of SYBR-Green Real-time PCR.

This was further corroborated by sequencing results from another field strain, positive in both tests, as well as the reference strain, which generated nucleotide sequences corresponding to RVA. Besides that, the NTC did not generate any signal as well as no cross-amplification of coronavirus was detected.

Salem et al. (2010) defined a detection limit of RVA detection primers after the second round PCR as being $10^{1}$ $\mathrm{TCID}_{50} / \mathrm{mL}$, but in a multiplex system, also including primers for porcine coronavirus (PEDV and TGEV), and due to modifications adopted in the current study (different RNA extraction and PCR mastermixes, primer binding areas, and monoplex system) there are limitations when comparing these performance results.

Similarly, Pang et al. (2004) reported that Real-Time PCR targeting the RVA NSP3 gene, using TaqMan system, was 1,000-fold more sensitive than conventional RT-PCR.

The analytical sensitivity of Real-time PCR was determined by a standard curve of serial dilutions in base 10 , which lower detection value was $1.04 \times 10^{1}$ copies $/ \mu \mathrm{L}$, with a correlation coefficient $\left(\mathrm{r}^{2}\right)$ of 0.998 and efficiency of $102.21 \%$, which are values within the expected range for this type of test. Similarly, the values of inter- and intra-assay reproducibility exhibited low coefficients of variation, below 3\% (Sariya et al. 2012). These results are similar to those reported by Ye et al. (2012), who develop a Real-Time PCR reaction for the NSP5 RVA gene and achieved an efficiency of $106 \%$ and $\mathrm{r}^{2}=0.997$, with a detection limit between $10^{8}$ and $10^{1}$ copies $/ \mu \mathrm{L}$.

Considering the advantages of SYBR Green Real-Time PCR, which include a lower chance of cross contamination due to a closed-tube system, quicker sample processing, and higher diagnostic sensitivity as compared to conventional PCR, the system developed in this study is an alternative for the diagnosis of RVA infection prevalent in porcine farms. This method has the potential to assist in the control and prevention of the disease.

Acknowledgements.- We thank the São Paulo Research Foundation- FAPESP (Proc, no.2011/10846-9) for providing financial support for this study.

\section{REFERENCES}

Akashi H., Inaba Y., Miura Y., Tokuhisha S., Sato K. \& Satoda K. 1980. Properties of a coronavirus isolated from a cow with epizootic diarrhea. Vet. Microbiol. 5:265-276.

Amimo J.O., Vlasova A.N. \& Saif L.J. 2013. Detection and genetic diversity of porcine group A rotaviruses in historic (2004) and recent (2011 and 2012) swine fecal samples in Ohio: predominance of the G9P[13] genotype in nursing piglets. J. Clin. Microbiol. 51:1142-1151.

Asano K.M., Souza S.P., Barros I.N., Ayres G.R., Silva S.O., Richtzenhain L.J. \& Brandão P.E. 2010. Multiplex semi-nested RT-PCR with exogenous internal control for simultaneous detection of bovine coronavirus and group A rotavirus. J. Virol. Methods 169:375-379.

Barbosa B.R., Bernardes N.T., Beserra L.A. \& Gregori F. 2013. Molecular characterization of the porcine group A rotavirus NSP2 and NSP5/6 genes from São Paulo State, Brazil, in 2011/12. Scient. World J. 2013:241686.

Caldwell J.M., Raley M.E. \& Levine J.F. 2007. Mitochondrial multiplex real-time PCR as a source tracking method in fecal-contaminated effluents. Environ. Sci. Technol. 41:3277-3283.

Contin R., Arnoldi F., Campagna M. \& Burrone O.R. 2010. Rotavirus NSP5 orchestrates recruitment of viroplasmic proteins. J. Gen. Virol. 91:17821793.

Criglar J.M., Hu L., Crawford S.E., Hyser J.M., Broughman J.R., Prasad B.V. \& Estes M.K. 2014. A novel form of rotavirus NSP2 and phosphorylation-dependent NSP2-NSP5 interactions are associated with viroplasm assembly. J. Virol. 88:786-798.

Dhama K., Chauhan R.S., Mahendran M. \& Malik S.V. 2009. Rotavirus diarrhea in bovines and other domestic animals. Vet. Res. Commun. 33:1-23.

Dorak M.T. 2006. Real-Time PCR. Taylor \& Francis Group, New York. 362p.

Estes M.K. \& Kapikian A.Z. 2007. Rotaviruses, p.1917-1974. In: Knipe D.M., Howley P.M., Griffin D.E., Lamb R.A., Martin M.A., Roizman B. \& Straus 
S.E. (Eds), Fields Virology. $5^{\text {th }}$ ed. Lippincott Williams and Wilkins, Philadelphia.

Ghosh S. \& Kobayashi N. 2011. Whole-genomic analysis of rotavirus strains: current status and future prospects. Future Microbiol. 6:10491065.

Gregori F., Brandão P.E., Rosales C.A.R., Cortez A., Heinemann M.B., Richtzenhain L.J. \& Jerez J.A. 2000. Desenvolvimento de um método de ELISA para a detecção de rotavírus a partir de material fecal. Arq. Inst. Biol. 67:191-194.

Gregori F., Brandão P.E. \& Jerez J.A. 2012. Diversidade intra-genotípica de amostras de rotavírus suínas circulantes no Estado de São Paulo, Brasil. Ars Vet. 28:28-35.

Herring A.J., Inglis N.F., Ojeh C.K., Snodgrass D.R. \& Menzies J.D. 1982. Rapid diagnosis of rotavirus infection by direct detection of viral nucleic acid in silver-stained polyacrylamide gels. J. Clin. Microbiol. 16:473-477.

Jerez J.A. 1997. Diarréias virais dos bezerros: rotavírus e coronavírus. Biológico, São Paulo, 59:33-37.

King A.M.Q., Adams M.J., Carstens E.B. \& Lefkowitz E.J. 2012. Virus Taxonomy: Classification and Nomenclature of Viruses: Ninth Report of the International Committee on Taxonomy of Viruses. Elsevier Academic Press, San Diego, p.603-613.

Larkin M.A., Blackshields G., Brown N.P., Chenna R., McGettigan P.A., McWilliam H., Valentin F., Wallace I.M., Wilm A., Lopez R., Thompson J.D., Gibson T.J. \& Higgins D.G. 2007. Clustal W and Clustal X version 2.0. Bioinformatics 23:2947-2948.

Matthijnssens J., Ciarlet M., McDonald S.M., Attoui H., Bányai K., Brister J.R., Buesa J., Esona M.D., Estes M.K., Gentsch J.R., Iturriza-Gómara M., Johne R., Kirkwood C.D., Martella V., Mertens P.P., Nakagomi O., Parreño V., Rahman M., Ruggeri F.M., Saif L.J., Santos N., Steyer A., Taniguchi K., Patton J.T., Desselberger U. \& Van Ranst M. 2011. Uniformity of rotavirus strain nomenclature proposed by the Rotavirus Classification Working Group (RCWG). Arch. Virol. 156:1397-1413.

Mijatovic-Rustempasic S., Tam K.I., Kerin T.K., Lewis J.M., Gautam R., Quaye O., Gentsch J.R. \& Bowen M.D. 2013. Sensitive and specific quantitative detection of rotavirus A by one-step real-time reverse transcription-
-PCR assay without antecedent double-stranded-RNA denaturation. J. Clin. Microbiol. 51:3047-3054.

Pang X.L., Lee B., Boroumand N., Leblanc B., Preiksaitis J.K. \& Yu Ip C.C. 2004. Increased detection of rotavirus using a real time reverse transcription-polymerase chain reaction (RT-PCR) assay in stool specimens from children with diarrhea. J. Med. Virol. 72:496-501.

Papp H., László B., Jakab F., Ganesh B., De Grazia S., Matthijnssens J., Ciarlet M., Martella V. \& Bányai K. 2013. Review of group A rotavirus strains reported in swine and cattle. Vet. Microbiol. 165:190-199.

Pestana E.A., Belak S., Diallo A., Crowther J.R. \& Viljoen G.J. 2010. Early, Rapid and Sensitive Veterinary Molecular Diagnostics - Real Time PCR Applications. Springer, Dordrecht, p.27-46.

Rodriguez C.A.R., Brandão P.E., Ferreira F., Gregori F., Buzinaro M.G. \& Jerez J.A. 2004. Improved animal rotavirus isolation in MA-104 cells using different trypsine concentrations. Arqs Inst. Biológico, São Paulo, 71:437441.

Salem A.N.B., Chupin S.A., Bjadovskaya O.P., Andreeva O.G., Mahjoub A. \& Prokhvatilova L.B. 2010. Multiplex nested RT-PCR for the detection of porcine enteric viruses. J. Virol. Methods 165:283-293.

SantaLucia J. 2007. Physical principles and visual-OMP software for optimal PCR design, p.3-34. In: Yuryev A. (Ed.), PCR Primer Design: methods in molecular biology. Humana Press, New Jersey.

Sariya L., Chatsirivech J., Suksai P., Wiriyarat W., Songjaeng A., Tangsudjai S., Kanthasaewee O., Maikaew U. \& Chaichoun K. 2012. Development of a SYBR Green I-based real-time PCR for detection of elephant endotheliotropic herpesvirus 1 infection in Asian elephants (Elephas maximus). J. Virol. Methods 185:160-165.

Thrusfield M. 2007. Veterinary Epidemiology, $3^{\text {rd }}$ ed. Wiley-Blackwell, Iowa, p. 305-330.

Ye X.Y., Ming X., Zhang Y.L., Xiao W.Q., Huang X.N., Cao Y.G. \& Gu K.D. 2012. Real-time PCR detection of enteric viruses in source water and treated drinking water in Wuhan, China. Curr. Microbiol. 65:244-253.

Zhu J., Yang Q., Cao L., Dou X., Zhao J., Zhu W., Ding F., Bu R.E., Suo S., Ren Y., Li G. \& Ren X. 2013. Development of porcine rotavirus vp6 protein based ELISA for differentiation of this virus and other viruses. Virol. J. 10:91. 